\title{
原発災害が被災住民にもたらした 精神的影響
}

辻内环也

\section{はじめに}

福島原発事故後 6 年間、筆者は内科・心療内 科の医師そして医療人類学を専攻する研究者と して、被焱者の身体・心理・社会的健康を目指 した支援と調査研究を継続させてきた。民間 支援団体「震災支援ネットワーク埼玉（SSN）」 の運営委員としても埼玉県における避難者支援 の企画運営に携わってきており、その一環とし て、(1)被災者の生活実態の総合的把握、(2)今後 の支援のあり方の検討、(3)行政への提言、の三 つを目標とした大規模アンケート調査を毎年お こなってきた。また、早稲田大学災害復興医療 人類学研究所（旧：早稲田大学「震災と人間科 学プロジェクト」) として、日本放送協会 (NHK) からの依頼を受け、「NHK スペシャル」等 ${ }^{[1,2,3,4]}$ の番組製作に伴う大規模調査を実施してきた。

本稿では、筆者らの研究チームがこれまでに 執筆してきた医学系原著論文および人文社会系 論文の要点を紹介し、原発災害がいかに過酷な 精神的被害を継続的にもたらし続けているかを 明らかにしていきたい。詳細については各論文 を参照していただきたい。

\section{福島原発災害1年後の被災住民に おける高い心的外傷後ストレス 症状と社会的因子との関連 ${ }^{(5)}$}

原発事故 1 年後の 2012 年にSSN との共同で、 福島県から埼玉県に避難中の 2,011世帯を対象 に調査を実施した。回収された490件（回収率 24.4\%）のうち、国際的に標準化された心的外 傷後ストレス症状を測定する質問紙「改訂出来 事インパクト尺度（以下IES-R）」の有効回答 者350件を分析した。

IES-Rの平均得点は 36.2 と高值であり、心的 外傷後ストレス障害（Post-traumatic Stress Disorder：PTSD）である可能性が出てくると される 25 点以上の者の割合が $67.3 \%$ 、さらに 高いストレス度でPTSD と診断できる可能性が あるとされる 30 点以上の者の割合が $59.4 \%$ で あった。

PTSD は、災害や大事故、戦争や紛争、犯罪 など、生命の危険性が高い出来事に伴うストレ ス障害を意味する。「自分または他人の生命の 危険を感じる精神的外傷体験による強い恐怖と 無力感」として定義される。

加藤ら ${ }^{[6]}$ は、阪神・淡路大震災（1995年） から約 4 年後の調查において、IES-R平均得点 22.5、25 点以上の者の割合 $39.5 \%$ と報告してい る。直井 ${ }^{[7]}$ は、新潟県中越地震（2004年） 13 か月後の 4,352 世帯を調査し、IES-R平均得点 
14.3、25点以上 $20.8 \%$ と報告している。ストレ 又量反応関係理論をもとにすれば、IES-Rの得 点の高さは災害による精神的インパクトの強さ を反映しており、筆者らの調査対象である原発 事故被災者が受けた精神的影響がいかに高いか が理解できるであろう。

さらに、多重ロジスティック回帰分析を用い てストレス症状に影響を及ぼしている各種要因 を解析したところ、身体的要因として「精神疾 患の持病、身体疾患の持病」、経済的要因とし て「生活費の心配、仕事の喪失」、社会的要因 として「近隣関係の希薄化、賠償問題の心配」 が明らかになった。ストレス症状のリスク要因 として、医学的要因だけではなく原発事故特有 の社会経済的問題が大きく関係していることが 明らかになった。

\section{原子力発電所事故による県外避難 に伴う近隣関係の希薄化 : \\ 埼玉県における原発避難者大規模 アンケート調査をもとに [8]}

前節で紹介した 2012 年調査のデータを別の 観点から分析し、避難によるコミュニティの崩 壊がもたらした精神的負荷について検討した。

災害前は、互いに相談したり日用品の貸し借 りをしたりするなど「生活面で協力しあう人」 が 10 人以上いると回答した者の割合が $25.9 \%$ であり、全国平均の $1.5 \%$ よ極めて高い值が 示された。しかし、災害後にはこの割合が $2.4 \%$ に減り、避難によって豊かな人間関係をもつコ

\section{PROFILE}

辻内环也 (つじうち たくや)

- 早稲田大学人間科学学術院教授

n早稲田大学災害復興医療人類学研究所

所長

專門 医療人類学

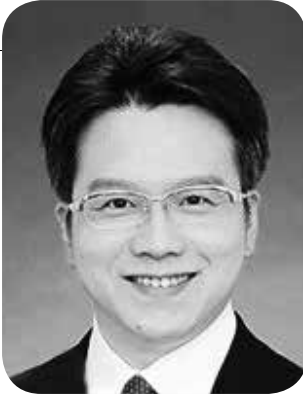

ミュニテイが断裂し、近隣関係が希薄化してい る実態が明らかになった。

次に、「生活面で協力しあう人」の人数が災 害前「10人以上」から災害後「0人」に減った 者41名を近隣関係「希薄化群」とし、それ以 外の者とIES-Rの得点を比較したところ、「希 薄化群」は 45.0 と高值であり「その他の群」の 35.4 点と比較して統計学的有意にストレス度が 高いことが確認された。今後は、近隣関係とい うソーシャルサポートの回復と、新たなコミュ ニティづくりを支援していく必要性が示され た。

\section{福島県内仮設住宅居住者にみられ る高い心的外傷後ストレス症状 : 原子力発電所事故がもたらした身 体・心理・社会的影響 ${ }^{\text {[9] }}$}

原発事故 2 年後の 2013年にNHKとの共同 で、福島県内の仮設住宅において生活する住民 2,425世帯を対象に調查を実施した。回収され た 745 件（回収率 $30.7 \%$ ）のうち、IES-Rの有 効回答者 661 名を分析した。

IES-Rの平均得点は 34.2 と高值であり、25点 以上の者の割合が $62.6 \%$ あった。多重ロジス ティック回帰分析で検討した結果、「持病の悪 化、新たな疾患の罹患、経済的困難、賠償の心 配、相談者の不在」といった、原発災害によっ 
てもたらされた数々の身体・心理・社会的状況 がストレス度に影響を与えていることが明らか になった。

これまでのPTSD研究のシステマティック・

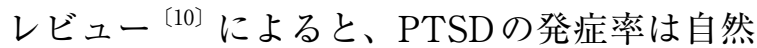
災害が約 4 〜 $60 \%$ なのに対し、人為災害は 15 〜 75\%と高いことが知られている。国会事故 調査委員会 ${ }^{[11]}$ が本災害を人為災害であると論 じているように、筆者らの調査結果は人為災害 としての特徵を指し示していると考えられた。 世界的にPTSD 発症率が高かった人為災害とし て知られる1994年の海難事件「エストニア号 事件」では、IES-Rを使用した生存者の調査に おいて、事件 3 か月後の平均が 42 点、 1 年後 34 点、 3 年後 34 点、 14 年後 33 点と高い值が続い ていた ${ }^{[12]}$ 。国をはさんでの事故原因に対する 論争が終結しておらず、研究者らはPTSDの長 期化には被害者に対する救済が行われずに不透 明な状況が長引いていることが関係している可 能性があると考察している ${ }^{[12]}$ 。わが国の原発 災害において、事故責任の不透明さや不十分な 救済といった要因が、高いストレス症状の要因 である可能性が見えてくる。

\section{東日本大震災に伴う原発事故によ} る県外避難者のストレス反応に及 ぼす社会的要因： 縦断的アンケート調查から ${ }^{[13]}$

原発事故から 1 年後に行った前述の 2012 年 調查と、2 年後に行った 2013 年調査を縦断的に
分析した。2013年調査は、埼玉県および東京 都在住の避難者 4,268 世帯に調査用紙を配布し、 499 件（回収率 $11.7 \%$ ）の回答を得、そのうち 有効回答者 429 名を分析した。

ストレス反応レベルを高值群・低值群に分け て、各種身体・心理・社会・経済的因子との間 でカイ二乗検定を行ったところ、2012年調査 では、男性において「生活費の心配、失業」、 女性において「住宅の被災状況、人間関係、賠 償問題」がストレス反応に影響しており、2013 年調査では男女ともに「苦しい経済状況、健康 状態の悪化、避難者というスティグマ、家族関 係や近隣関係、住環境」がストレス反応に影響 していることが示された。

\section{福島原子力発電所事故により県外 避難する高齢者の個人的レベルの ソーシャル・キャピタルとメンタ ルヘルスとの関連}

原発事故から 3 年後の 2014 年調査は、SSN と 共同し埼玉県および東京都に避難中の 3,599世 帯を対象に行われた。回収された 772 件（回収 率 $21.5 \%$ ）のうち 65 歳以上の 229 名を分析対象 として、社会の中での人々の信頼意識やつなが りといったソーシャル・キャピタル (以下 SC) ${ }^{[15]}$ とストレスとの関連を多重ロジスティックモデ ルを用いて調べた。

その結果、「近隣住民への信頼、助け合いの 意識」などの SC の認知的指標や、「近隣で挨拶 を交わす人数、趣味や娛楽活動への参加頻度」 
といったSCの構造的指標が低い群ほど、高い ストレス状態にあることが統計学的に示され た。したがって、メンタルヘルスの向上には 豊かな SCの醸成が不可欠であることが示され た。

大規模調査からみる自主避難者の 6 特徵:「過剩な不安」ではなく「正 当な心配」である〔16]

2015年にNHKと共同で、東日本大震災およ び原発事故により仮設住宅・みなし仮設住宅に おいて避難生活を送っている、福島県 16,686 世 帯、宮城県 27,271 世帯、岩手県 12,187 世帯を対 象に調査を実施し、回収された 11,377 件（回収 率 $20.3 \%$ ）を分析した。この論文では、福島県 から全国に避難している者のうち、自主避難者 622 件の特徵を強制避難者 1,870 名と比較して 論じた。

「避難者であることによる嫌な経験」の有無 を尋ねたところ、「よくある、少しある」を合 計すると、自主避難者が約 $41 \%$ 、強制避難者 が約 $50 \%$ であった。これに対して宮城県の避 難者は約 $22 \%$ 、岩手県は約 $26 \%$ であり、福島 県の避難者では圧倒的に多くの人々が嫌な経験 をしていることが示された。また、「避難して きていることを地域の人に話すことへの抵抗 感」について尋ねたところ、「抵抗がある、ど ちらかというと抵抗がある」を合計して、自主 避難者が約 $48 \%$ 、強制避難者が約 $51 \%$ であっ た。一方、宮城県は約 $16 \%$ 、岩手県は約 $11 \%$
であった。これらの現象は原発災害の大きな特 徵であり、遠隔地かつ広域の避難を余儀なくさ れたことと、“放射能”や“賠償金”というスティ グマによる被害だと推察された。

自主避難者らの自由記述を分析したところ、 『安全・安心神話への疑義』と『価值観の対立』 というカテゴリーが抽出された。福島の放射線 量は高くなく安心・安全に住むことが出来る、 という考え方ばかりが行政や県民によって強調 されている点への批判と、深刻な近隣間や家族 間の価值観の対立が認められた。この現象の根 本にある問題として、(1)国や東京電力に対する 不信と、(2)放射線の健康影響に関する専門家間 の見解の相違、の二点が考えられた。

放射線に関する科学リテラシーについても評 価を行った。「放射線と放射能は違っており明 確に区別ができる」と回答した者の割合が、宮 城県と岩手県そして福島県における津波被災者 では約 $11 〜 14 \%$ であるのに対して、強制避難 者が約 33\%で自主避難者は約 $37 \%$ であり、明 らかにリテラシーが高い。この結果から、一般 的によく言われている「自主避難者たちは放射 線に関して無知だから、過剩に不安になって避 難している」という言説が否定できると考えら れた。

事故前の平時の公衆の被曝限度は年間 $1 \mathrm{mSv}$ であった。原子力施設作業者の放射線被曝によ る労災認定基準が年間 $5 \mathrm{mSv}$ であり、放射性 物質を扱う施設の放射性管理区域の基準が年間 に換算すると $5.2 \mathrm{mSv}$ である。日野 ${ }^{[17]}$ が述べ ているように、一般の住民には被曝を受忍すべ 
き過失も責任もないのであるから、平時の公衆 の被曝限度を超えた場合には避難できる権利を 有していると考えられ、ここに自主避難の合理 性が認められる。現在、年間 $20 \mathrm{mSv}$ を下回る 区域として指定された「避難指示解除準備区域」 の解除が次々と進められているが、帰還しない で長期避難を継続する権利を住民に保障すべき である。

\section{原発事故がもたらした精神的被害： 構造的暴力による社会的虛待 ${ }^{[18]}$}

構造的暴力（structural violence）という言 葉は、平和研究創始者のひとりであるヨハン・

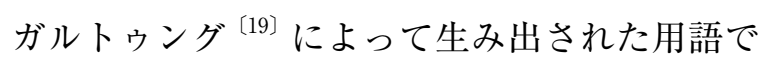
あり、医療人類学者ポール・ファーマー ${ }^{[20]} も$ ハイチの災害における貧困と健康の不平等の分 析に使用している。わが国の原発事故後に被災 者が追い込まれている状況を分析すると、まさ に構造的暴力による不正義・不平等 · 格差 - 差 別であることが理解できる。原発事故という暴 力によって「生活・人生・環境」に関わるすべ てが根こそぎ奪われ、その後の帰還優遇政策や 賠償・支援をめぐる政策決定が継続する構造的 暴力となって、被災者の生活や人生を蹂躀して いると考えられた。

暴力の下部構造として、原子力発電という開 発を推進してきた戦後の経済政策、大企業優先 の経済政策による富の不平等分配、中央対地方 という地政学的な搾取の構造、自由主義という 名の競争原理に基づく社会格差を生み出す構
造、自己責任論を基礎とした医療・福祉におけ る社会責任の放棄、核の平和利用を抑止力とし て使った戦後の国家安全保障、といった構造が 重層的に存在していると考えられた。

さらに被災者の状況にはドメスティック・バ イオレンスや虐待における暴力との類似点が認 められ、そこには生活や人生の決定権が奪われ、 社会的孤立に追い込まれる社会的虐待（social abuse）と考えられる状況が認められた。

\section{おわりに}

これまでに筆者らの研究チームが明らかにし てきた研究成果から、以下のような提言を行い たい。

1）ストレスには身体・心理・社会・経済・住 環境問題が複合的に関与しており、ストレス の改善には「こころのケア」だけでなく社 会・経済・環境問題の解決、すなわち「社会 的ケア」が必須である。

2）ストレスには近隣関係の希薄化や低いソー シャル・キャピタルが強く関与して扮り、コ ミュニティづくりや人々の信頼意識やつなが りの醸成が必要である。

3）ストレスの持続には人為災害の特徴が現れ ており、事故責任の明確化や十分な救済が重 要である。

4）避難者というスティグマが存在しており、 疎外や差別に対する対策が必要である。

5）安全・安心神話によって価值観の対立が生 じており、対話による双方の価值観の容認が 
課題である。

6）年間 $1 \mathrm{mSv}$ 超える地域からの「避難する 権利」が認められるべきである。また、自主 避難者は放射線被曝に対して過剩な不安を 持っているのではなく、正当な心配をしてい るのだと考えられ、避難の合理性が認められ るべきである。

7）年間 $20 \mathrm{mSv}$ 以下の地域であっても「帰還し ない権利」あるいは「長期避難を継続する権 利」が認められ、相応の支援が受けられるよ うにすべきである。

8）原発災害被害者は構造的暴力により生活や 人生が蹂䠰されていると考えられ、政治・経 済・社会・文化などの構造に組みこまれてい る不正義 - 不平等 - 格差 - 差別の根本的解決 を目指さなければならない。

\section{引用文献}

〔1〕「3.11あの日から2年、福島のいまを知っていますか〜西 田敏行が見つめる福島のいま〜」NHKスペシャル, 2013 年3月9日放映.

２〕「シリーズ東日本大震災 震災 4 年 被災者 1 万人の声〜復興 はどこまで進んだのか〜」NHKスペシャル，2015年3月8 日放映。

〔3〕「“帰りたい...帰れない...” 〜福島の避難者 それぞれの選 択〜」NHKクローズアップ現代, 2015年3月11日放映.

〔4〕「原発事故・避難者アンケート一何が福島の人々を苦しめ ているのか一」NHKハートネットTV, 2015年5月27日放 映.

[5] Takuya Tsujiuchi, Maya Yamaguchi, Kazutaka Masuda, et al.: High prevalence of post-traumatic stress symptoms in relation to social factors in affected population one year after the Fukushima nuclear disaster. PLoS ONE 11(3):e0151807. doi:10.1371/journal.pone.0151807, 2016.

[6] Kato H, Iwai K: Posttraumatic stress disorder after the Great Hanshin-Awaji Earthquake: assessment by the structured interview to the survivors. Med J Kobe Univ 60: pp147-155, 2000.

[7] Naoi K: Local mental health activity after the Niigata-ken Chuetsu Earthquake: Findings of investigations performed three and half months and thirteen months after the earthquake, and analysis about the risk factor of PTSD. JPN Bull Soc Psychiat 18: pp52-62, 2009.

（8〕増田和高, 辻内琢也, 山口摩弥, 他: 原子力発電所事故によ る県外避難に伴う近隣関係の希薄化; 埼玉県における原発 避難者大規模アンケート調査をもとに. 厚生の指標60(8): pp9-16, 2013.

（9）辻内琢也, 小牧久見子, 岩垣穂大, 他: 福島県内仮設住宅居 住者にみられる高い心的外傷後ストレス症状一原子力発 電所事故がもたらした身体・心理・社会的影響一. 心身医 学56(7): pp723-736, 2016.

[10] Neria Y, Nandi A, Galea S: Post-traumatic stress disorder following disasters: a systematic review. Psycho Med 38: pp 467-480, 2007.

[11] Kurokawa K, Ishibashi K, Oshima K, et al. The official report of the Fukushima nuclear accident independent investigation commission: Executive summary. Tokyo: The National Diet of Japan; pp38-41, 2012.

[12] Arnberg FK, Eriksson NG, Hultman CM, et al: Traumatic bereavement, acute dissociation, and posttraumatic stress -14 years after the MS Estonia disaster. J Traum Stress 24: pp183-190, 2011.

〔13〕山口摩弥, 辻内玩也, 増田和高, 他: 東日本大震災に伴う 原発事故による県外避難者のストレス反応に及ぼす社会 的要因〜縦断的アンケート調査から〜 . 心身医学56(8) : pp819-832, 2016.

〔14〕岩垣穂大, 辻内琢也, 増田和高, 他: 福島原子力発電所事故 により県外避難する高齢者の個人レベルのソーシャル・ キャピタルとメンタルヘルスとの関連. 心身医学, 57(2) : pp173-184, 2017.

〔15]相田潤, I. カワチ. S.V.スブラマニアン, 他: 災害とソー シャル・キャピタルと健康, 日本評論社, pp207-228, 2013.

[16]辻内琢也: 大規模調査からみる自主避難者の特徵;「過剩 な不安」ではなく「正当な心配」である.戸田典樹（編）： 福島原発事故・漂流する自主避難者たち。明石書店, pp27-64, 2016.

〔17〕日野行介: 冷たい復興; みなし仮設打ち切りで漂流する自 主避難者. 岩波書店, 世界872: pp108-116, 2015.

[18] 辻内琢也: 原発事故がもたらした精神的被害: 構造的暴力 による社会的虐待. 岩波書店, 科学 86(3): pp246-251, 2016.

[19] ヨハン・ガルトゥング（著），高柳先男・塩屋保・酒井由 美子（訳）: 構造的暴力と平和. 中央大学出版部, 1991.

〔20ポール・ファーマー（著），豊田英子（訳）：権力の病理 一誰が行使し誰が苦しむのか、医療・人権・貧困. みすず 書房, 2012. 